\title{
Control of aquifer weathering degree to the groundwater chemical composition in Wates Coastal Aquifer, Yogyakarta, Indonesia
}

\author{
Heru Hendrayana ${ }^{1 *}$, Phyu Phyu Thin ${ }^{2}$, Wahyu Wilopo ${ }^{1,3}$, and Satoru Kawasaki ${ }^{4}$ \\ ${ }^{1}$ Department of Geological Engineering, Faculty of Engineering, Universitas Gadjah Mada, Yogyakarta, 55581, Indonesia \\ ${ }^{2}$ Department of Engineering Geology, Yangon Technological University, Gyogone, Insein, Yangon, 11011, Myanmar \\ ${ }_{3}$ Center for Disaster Mitigation and Technological Innovation (GAMA-InaTEK), Universitas Gadjah Mada, Yogyakarta, 55581, \\ Indonesia \\ ${ }^{4}$ Division of Sustainable Resources Engineering, Faculty of Engineering, Hokkaido University, Sapporo, 60-8628, Japan
}

\begin{abstract}
The studied coastal aquifer has been encountered a complex hydrochemical evolution. Interesting aspect is the occurrence of groundwater facies with different water chemistries in close proximity to each other. Water salinity is reported from local parts away from shore. This research was conducted for assessment of aquifer weathering and its control on groundwater chemistry. An investigation of major ions in 27 water samples was performed with geostatistics, graphical method, mineral saturation index and mass balance transport to identify the groundwater evolution. Geochemical analysis of sediments was made of 8 samples, to estimate the weathering degree using chemical index of alteration and chemical index of weathering. Silicate dissolution was promoted by low weathering, which was reflected in low ions dominated by calcium and bicarbonate in fresh water. It leaded to fine sands. Silts were dominant under moderate weathering. Sodium and calcium were higher than fresh water. Bicarbonate was still highest concentration. Main water was the mixed type which was indicated by moderate ions. Clays were formed by high weathering. Water salinity with highest dissolved solids was caused by halite dissolution and calcium adsorption on clays. Overall, groundwater chemistry in the study area is locally characterized by prevailing lithology in grouping patterns.
\end{abstract}

\section{Background}

Fresh water stored in the coastal aquifers is particularly susceptible to quality deterioration because of sea water proximity. Sea water intrusion has become a worldwide alarm [1]. Groundwater chemical composition depends on several processes: (i) mixing of saline water from various origins (marine intrusion, former trapped sea water,etc.) with fresh water of aquifer, (ii) rock-water interactions through chemical dissolution/precipitation of aquifer materials, (iii) evaporation and (iv) cation exchange processes on clay [2]. Concomitantly, geochemical processes involve the interaction of lithology with water leading to the development of secondary minerals [3]. The mineralogy of weathering products can be facilitated by the degree of chemical weathering of prevailing lithology. These driving factors and their interrelations can be superimposed for a same aquifer and create the critical groundwater facies [4].

The study area, which is bordered with the Indian Ocean has been encountered a very complex hydrochemical evolution. One of the interesting aspects of hydrochemistry is the occurrence of groundwater facies with different water chemistries in very close proximity to each other $[5,6]$. The luck of similarity in groundwater fa-

*Corresponding author: heruha@ugm.ac.id cies is moving a burning problem and it is compounded by issue of water salinization. High salinity in water is reported from small local parts, especially away from shore line $[5,7]$ and is a matter of great concern. Keeping this in view, sea water intrusion has been attacking the local shallow aquifer. No integrated geochemical characterization of aquifer materials has been done till now including the changes in hydrochemistry. The study area is composed of the sediments of marine origin [8], which might also be partly responsible for ionic changes in groundwater. An attention was being given to consider the aquifer weathering to arrive at meaningful interpretation. Considering all the above findings, the present study was carried out with objectives for assessment of aquifer weathering degree and its control on groundwater chemistry. In addition, chemical index of alteration (CIA), chemical index of weathering (CIW), geostatistical technique, graphical method, mineral saturation index (SI) and mass balance transport were adopted in the present study to identify the source of groundwater evolution. This research intends to highlight such issues if any; for future implementation of preventive measures.

\section{Study area}

The present study was conducted in the Wates coastal area. It is one of the principal parts of southern Kulon Progo, Indonesia. This part of Kulon Progo is situated between the 
latitudes $7^{\circ} 50^{\prime} 00^{\prime \prime}$ and $7^{\circ} 56^{\prime} 00^{\prime \prime} \mathrm{S}$, the longitudes $110^{\circ}$ $05^{\prime} 00^{\prime \prime}$ and $110^{\circ} 07^{\prime} 00^{\prime \prime} \mathrm{E}$. The study area covers about $32 \mathrm{~km}^{2}$ geographically and it is bounded to the south by Indian Ocean (Fig. 1). Topographically, it is a flat plane with an average elevation of $50 \mathrm{~m}$ above mean sea level. The Kali Serang River runs across the study area and drains into the Indian Ocean.

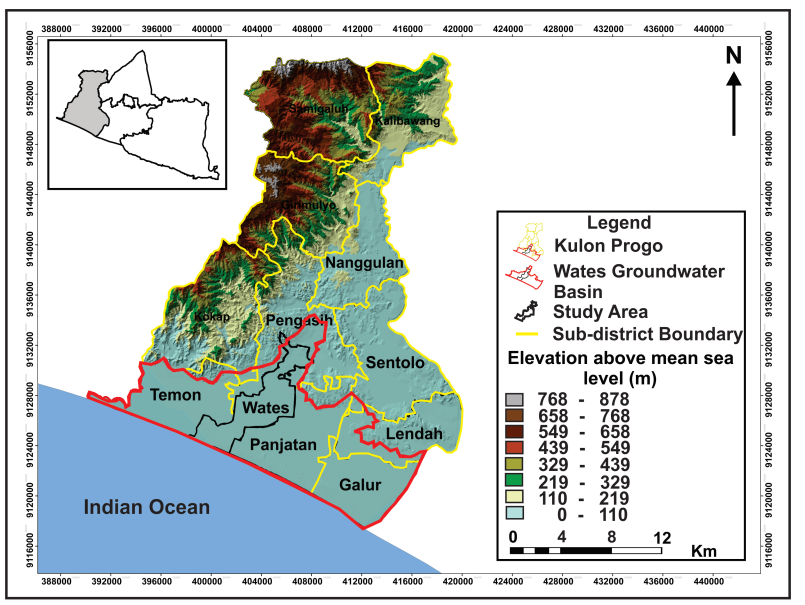

Fig. 1. Location map of the study area

\section{Geomorphology}

The study area shows distinct morphological features, which can be divided into two units such as the Fluviomarine Plain $\left(\mathrm{F}_{\mathrm{m}}\right)$ and Sand Dunes (Fig.2).Former shallow marine (lithoral) zone which was developed as the Fluviomarine Plain $\left(\mathrm{F}_{\mathrm{m}}\right)$ during the Pleistocene-Holocene age, are composed of sediments, which are a mixture of marine activity and fluvial deposits originating from the erosion process of northern hill sides. This unit has a flat morphology with a slope of 0-3\%. As the result of fluvial deposits due to river flow, former shallow marine (lithoral) zone and lagoon are covered by alluvial sediments but do not continuously fill. The resulting layers, which form the Fluviomarine Plain $\left(\mathrm{F}_{\mathrm{m}}\right)$ has the intermitted structures. In the southern area which borders directly with the Indian Ocean, the units of Sand Dunes consist of sediments aged in the Holocene which were developed by the collaboration of marine and eolian processes, in the form of Young Beach $\left(\mathrm{M}_{1}\right)$, Sand Dunes and Swales (E), and Old Beach Ridges $\left(\mathrm{M}_{2}\right)$. These units have a morphology with slopes of 3-8\%. At a border of Fluviomarine Plain $\left(\mathrm{F}_{\mathrm{m}}\right)$ and Old Beach Ridges $\left(\mathrm{M}_{2}\right)$, there is a stratum of marine clays as the confining unit.This phenomenon is estimated as a main cause why the system of groundwater from northern hilly ceases at the Fluviomarine Plain $\left(\mathrm{F}_{\mathrm{m}}\right)$ because of being hindered by the Old Beach Ridges $\left(\mathrm{M}_{2}\right)$ [8].

\section{Methodology}

First of all, groundwater flow direction was taken into consideration in order to locate right water sampling with the presence of suspected groundwater evolution. As a matter fact, 27 water samples were collected from different locations (Fig.2) and sent to laboratory for knowing major ionic concentrations. The $\mathrm{pH}$, temperature $(\mathrm{T})$, electrical conductivity (EC) and total dissolved solids (TDS) were immediately measured in field using the water test kit that was calibrated beforehand. Measurement of groundwater level was done in all locations. Ionic balances were within 5\% range, except for location 17.Piper diagram [9] was used to plot the chemical data in order to determine the groundwater facies. Several computer programs have been utilized, which include:Aquachem software to carry out the graphical analysis, ArcMap software to construct the spatial distribution map and PHREEQC program to compute the mineral saturation index (SI) with respect to a stated water composition and mass balance transport to identify the mineral alteration reaction. A positive SI value indicates over-saturation, whereas a negative SI points out under-saturation and enhances the dissolution of minerals into groundwater. There is nearly equilibrium into groundwater if SI value ranges between -0.5 and +0.5 and there is no dissolution and no precipitation for relative mineral [10]. A sediment sampling network was set up to allow a collection of representative data of the variability in more or less similar dissolved solids locations. This network consists of 8 locations (Fig.2) with drilling until $2 \mathrm{~m}$ depth and sent to laboratory for geochemical study with the Inductively Coupled Plasma Mass Spectrometry method.To know the weathering degree of sediments, the chemical index of alteration (CIA) and chemical index of weathering (CIW) were calculated by following equations.

$$
\begin{gathered}
\mathrm{CIA}=\left[\mathrm{Al}_{2} \mathrm{O}_{3} /\left(\mathrm{Al}_{2} \mathrm{O}_{3}+\mathrm{CaO}^{*}+\mathrm{Na}_{2} \mathrm{O}+\mathrm{K}_{2} \mathrm{O}\right)\right] \times 100 \\
\mathrm{CIW}=\left[\mathrm{Al}_{2} \mathrm{O}_{3} /\left(\mathrm{Al}_{2} \mathrm{O}_{3}+\mathrm{CaO} \mathrm{O}^{*}+\mathrm{Na}_{2} \mathrm{O}\right)\right] \times 100
\end{gathered}
$$

In here, $\mathrm{CaO} *$ represents calcium in silicate-bearing minerals. Weathering values below $50 \%$ are fresh, the values between 50 and $60 \%$ are low, the values between 60 and $80 \%$ are moderate and the greater values than $80 \%$ are extreme.To examine the weathering products, major elements were plotted on the $\mathrm{Al}_{2} \mathrm{O}_{3}-\left(\mathrm{CaO}^{*}+\mathrm{Na}_{2} \mathrm{O}\right)-\mathrm{K}_{2} \mathrm{O}$ (A$\mathrm{CN}-\mathrm{K})$ and $\mathrm{Al}_{2} \mathrm{O}_{3}-\left(\mathrm{CaO}^{*}+\mathrm{Na}_{2} \mathrm{O}+\mathrm{K}_{2} \mathrm{O}\right)-\left(\mathrm{Fe}_{2} \mathrm{O}_{3}+\mathrm{MgO}\right)$ (A-CNK-FM) plots [11].

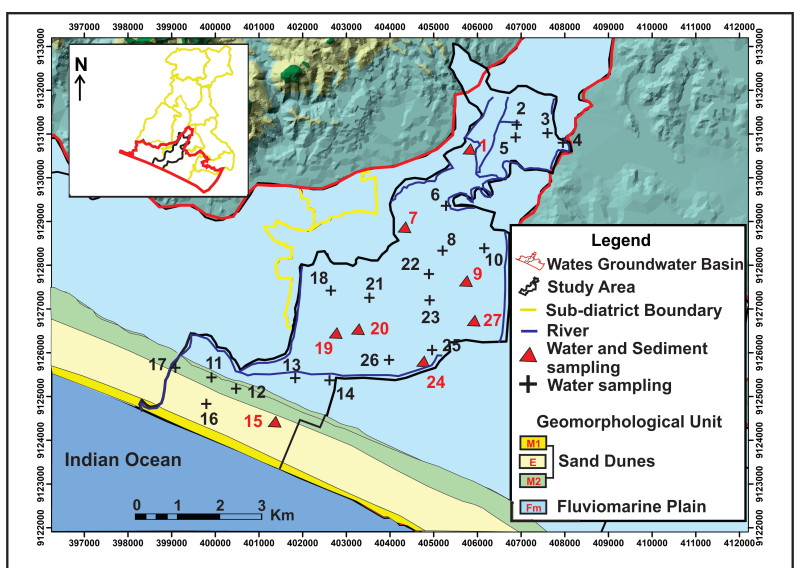

Fig. 2. Sampling locations on different geomorphological units of the study area

\section{Results}

\subsection{Weathering degree}

Based on the results of X-ray diffraction (XRD), the studied samples are rich in quartz, plagioclase feldspars and 
clay minerals $[5,7]$. The weathering of feldspars leads to the formation of clay [12]. Referring to this concept, it is assumed that feldspar weathering will play an important role. The reason for using the CIA and CIW is to assess the chemical weathering state of plagioclase feldspars. In Fluviomarine Plain $\left(\mathrm{F}_{\mathrm{m}}\right)$, the CIA and CIW values show a different range of weathering values; low degree in locations 1, 24 and 27, moderate in locations 7, 9 and 20, and high in location 19. It displays that the variation is relatively small and CIA value is slightly higher than CIW. The difference can be explained by the fact that CIA includes $\mathrm{K}_{2} \mathrm{O}$ in its calculation while CIW is omitting it. The only value which is significantly lower is location 15 collected from Sand Dunes Units. The CIA value is $48 \%$. Likewise, the CIW value shows $43 \%$. It shows that weathering has not clearly occurred. The differences between most weathered index values in Fluviomarine Plain $\left(\mathrm{F}_{\mathrm{m}}\right)$ and Sand Dunes Units are in the ranges of 35\% for CIA and 38\% for CIW. It shows that the variation between weathering calculation is relatively high. Probably, the Sand Dunes Units show the variation in weathering grade with the Fluviomarine Plain $\left(\mathrm{F}_{\mathrm{m}}\right)$.

To provide a better understanding of weathering trends and their products, major element concentrations were plotted on the A-CN-K diagram. In Fig.3 (a), location 15 plots approximately $48 \%$ to $\mathrm{A}$ apex $\left(\mathrm{Al}_{2} \mathrm{O}_{3}\right)$ below feldspar join but close to left boundary (A-CN side).Low CIA value indicates a possibility of mafic minerals in Sand Dunes Units [11]. Locations 1, 24 and 27 which are in low weathering are found from $54 \%$ to $59 \%$ to A apex above feldspar join. Locations 7, 9 and 20 with moderate weathering fall in nearly same region as the points of low weathering. This means that overall compositions of sediments, which are located in these points as a cluster are not varying much. Location of 19 plots about $83 \%$ to A apex. Since the sediments in the study area are rich in montmorillonite and anorthite $[5,7]$, they have high calcium content as well as low content of $\mathrm{K}_{2} \mathrm{O}$. As a result, most of samples are nearly parallel to A-CN side above feldspar join.

In comparison with first plot, some differences are observable in Fig.3 (b). Data points move from left to opposite side of ternary that means they contain both felsic and mafic components. Location 19 marked with high weathering moves along ternary axis up to montmorillonite. The points which are in low and moderate weathering lie above feldspar join on the A-CNK boundary to FM apex and show a close relationship between them. By taking a best fit line through their points, ternary plots show that the weathering trends are following same direction and leading to the formation of montmorillonite, which is a product of high weathering. Location 15 is moving down to $\mathrm{FM}$ apex $\left(\mathrm{MgO}+\mathrm{Fe}_{2} \mathrm{O}_{3}\right)$ corner due to its high concentration in these oxides.Consequently, it is not under weathering condition because of the presence of marine and eolian sands, which consist of hemtite and augite. Weathering products in all locations of both ternary plots were clearly confirmed by the result of XRD [5, 7].It is one of the evidences for chemical weathering degree.

As the correlation result of drill log [13] and geoelectric data [8], detailed geological map of the study area can

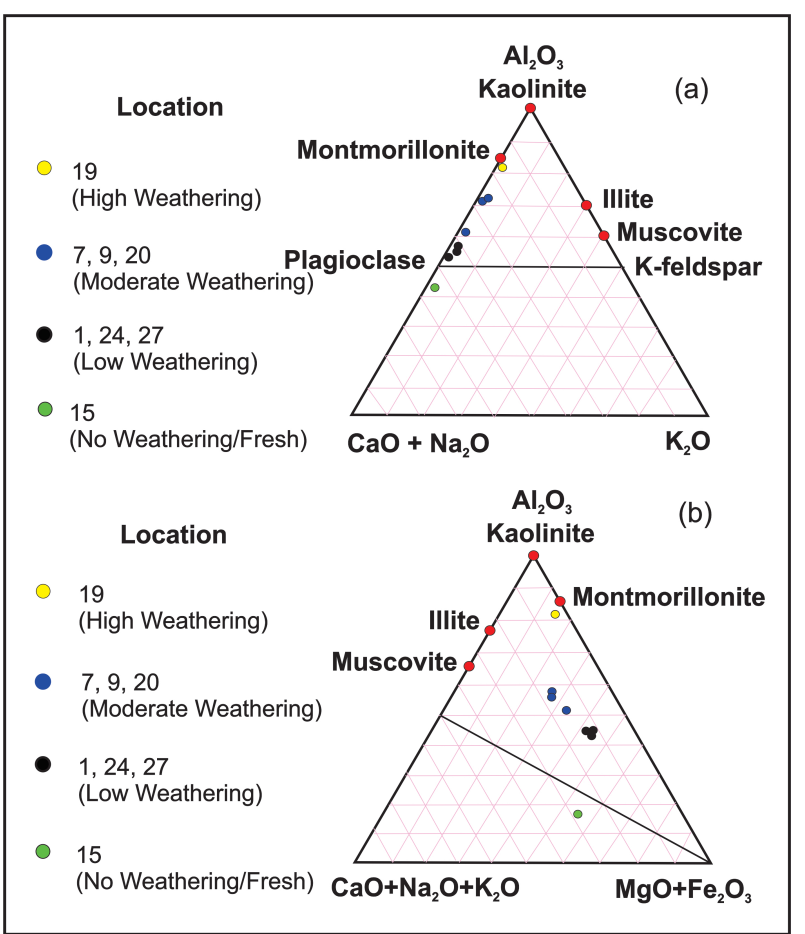

Fig. 3. Ternary plots showing the oxides; (a) $\mathrm{Al}_{2} \mathrm{O}_{3}-(\mathrm{CaO}+$ $\left.\mathrm{Na}_{2} \mathrm{O}\right)-\mathrm{K}_{2} \mathrm{O}$ and (b) $\mathrm{Al}_{2} \mathrm{O}_{3}-\left(\mathrm{CaO}+\mathrm{Na}_{2} \mathrm{O}+\mathrm{K}_{2} \mathrm{O}\right)-\left(\mathrm{MgO}+\mathrm{Fe}_{2} \mathrm{O}_{3}\right)$

be seen in Fig.4. In northern and middle parts of Fluviomarine Plain $\left(\mathrm{F}_{\mathrm{m}}\right)$, this unit is dominated by Wates Formation $\left(\mathrm{W}_{1}\right)$ in the form of fluvial (river) clay, silt and fine sand at the top, and marine (lithoral) clay, silt and fine sand containing mollusks fossils at the bottom from the Pleistocene to Holocene age. In the south, this unit is dominated by marine (wave) activity in the form of marine clay mixed silt containing mollusks, which constitute the materials of Pleistocene to Holocene age. It was identified by Wates Formation $\left(\mathrm{W}_{2}\right)$. Based on the result of geoelectric survey, the upper layers of Sand Dunes are composed of saturated marine and eolian sands marked by groundwater level. At the bottom, it is composed of marine clay mixed with silt and fine sand. Considering this, drill log and geoelectric data provide strong evidences that the types of lithology which act as aquifer and aquitard are sand, silt and clay. The weathering grades and their products are reliable to data presented by MacDonald and Partners (1984) and Santosa (2010), who investigated the geology and hydrostratigraphy in the southern part of Kulon Progo.

\subsection{Groundwater flow}

The depth of water table from mean sea level varies from 2.2 to $10.6 \mathrm{~m}$ in the Fluviomarine Plain $\left(\mathrm{F}_{\mathrm{m}}\right)$ and 1.3 to $6.3 \mathrm{~m}$ in the Sand Dunes, respectively. Groundwater level was interpolated with Kriging using ArcMap (Fig.6). The map reveals that local groundwater recharges, from which groundwater moves away in various directions, are observed at locations of both units. In northern and eastern parts of the Fluviomarine Plain $\left(F_{m}\right)$, the groundwater contours are closely spaced, which is likely because of high permeable nature of the prevailing lithology. In central and south-western parts, the hydraulic gradients are 


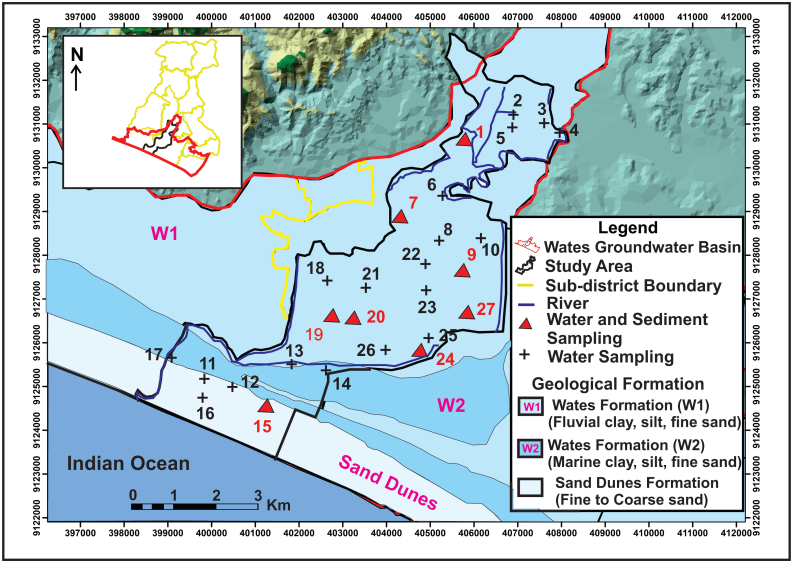

Fig. 4. Detailed geological map based on drill $\log$ and geoelectric data in the study area $[13,8]$

slightly flattened; the groundwater moves towards these depressions from the surrounding recharge. In here, the contours are widely spaced, indicating less permeability of lithology. As a result, the groundwater to be salty is indicated by high TDS. In northern part of Fluviomarine Plain $\left(\mathrm{F}_{\mathrm{m}}\right)$, the groundwater generally flows from north to south. However, in central and southern parts of this unit the Kali Serang River discharges to groundwater because of higher water level than that of groundwater. Therefore, the groundwater flow moves from east to west. The remarkable groundwater flow on the Fluviomarine Pain $\left(\mathrm{F}_{\mathrm{m}}\right)$ stops in northern boundary of Sand Dunes Units (Old Beach Ridges $\left(\mathrm{M}_{2}\right)$ ). On the Sand Dunes, it shows a specific groundwater flow pattern in all directions. The Old Beach Ridges $\left(\mathrm{M}_{2}\right)$ are mainly composed of clay which is the result of marine process. Clay layer becomes the limiting plane which is likely to flow into the Sand Dunes Units the groundwater from the Fluviomarine Plain $\left(\mathrm{F}_{\mathrm{m}}\right)$. This sub-system is a former beach that has experienced the movements of coast line are increasingly moving towards the Indian Ocean. It can be seen from the sign of change in the direction of river suddenly. The change in flow direction follows the former shore line. It can also be seen from dissolved solids in this area that tends to be low compared to the surrounding area. Therefore, in the study area there is a real relationship between groundwater flow and prevailing lithology [5].

\subsection{Groundwater facies}

Since the weathering grades of CIA and CIW calculations are not similar, it can be expected that there will be different the concentrations of dissolved solids and water types which were classified by the Piper diagram. It is a graphical presentation of groundwater that categorizes the samples in terms of how concentrated they are with specific major ions [9]. The plotting result of hydrochemical data falls under three groups of groundwater facies (Fig. 5), demonstrating that water samples occupy a wide area of the Piper diagram ranging from fresh to saline waters [5, 6]. To further understand the variation and distribution of groundwater facies, all water types on different morphologicl units are shown in Fig. 6.

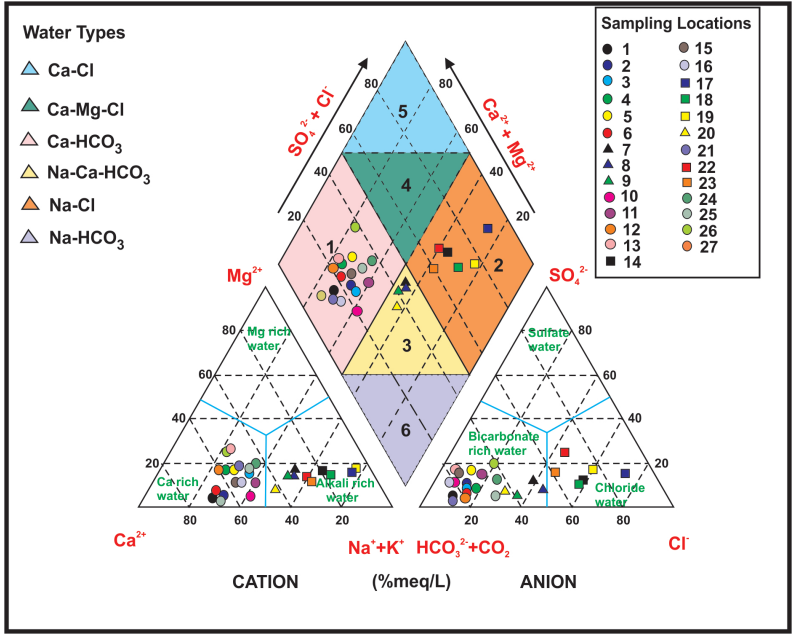

Fig. 5. Piper diagram showing the chemical composition of water samples $[5,6]$

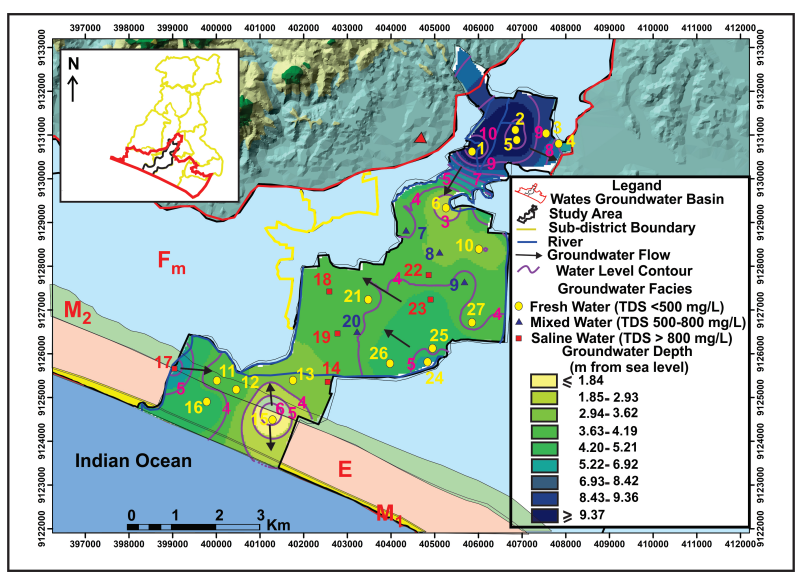

Fig. 6. Groundwater level contour map and spatial distribution of groundwater facies [5]

\subsubsection{Fresh water}

As seen in Fig. 2, the sampling locations 1, 2, 3, 4, 5, 6, $10,11,12,13,15,16,21,24,25,26$ and 27 are dominated by $\mathrm{Ca}-\mathrm{HCO}_{3}$ water. The groundwater belonging to fresh water is commonly found throughout the study area. This indicates that the hydrochemical properties are mostly similar in here. It is characterized by more diluted chemistry with TDS $(310-450 \mathrm{mg} / \mathrm{L})$. This water is known as recently recharged groundwater because of its high $\mathrm{Ca}^{2+}$ and $\mathrm{HCO}_{3}{ }^{-}$concentrations.

\subsubsection{Mixed water}

Compared to above locations, the $\mathrm{Na}-\mathrm{Ca}-\mathrm{HCO}_{3}$ type water has a TDS ranging from 520 to $740 \mathrm{mg} / \mathrm{L}$, showing moderate concentration of dissolved solids. The locations 7, 8, 9 and 20 are basically consistent with fresh water. Consequently, this water was not enriched in any kind of specific ions, hence it was categorized as the mixed type. This might be due to the mixing of old groundwater and recharged water. It is worth nothing that mixed water has not significantly altered by different dissolve solids yet. 


\subsubsection{Saline water}

The samples 14, 17, 18, 19, 22 and 23 are of $\mathrm{Na}-\mathrm{Cl}$ type, which has local variation tendency of hydrochemical composition apart from others. This water could be old groundwater; there is a possibility of very low recharge if the water is contained in a semi-confined aquifer (aquitard). Therefore, as the groundwater moves down-gradient in aquifer it is enriched in these ions through mineralization with an excess of $\mathrm{Na}^{+}$and $\mathrm{Cl}^{-}$ions. As the consequence, saline water dominates in locally sampling points which consist of highest dissolved solids $(1,000-1,030 \mathrm{mg} / \mathrm{L})$ in groundwater. Fig.6 also shows that groundwater facies change from up-gradient area to downgradient. This is an indication of possible hydrochemical processes that might be taking place along flow path. Geologically, the study area is underlain by the Alluvial deposits of Quaternary age consisting of sand, silt and clays $[13,8]$. As water flows underground, it reacts with aquifer materials to give the resultant facies of groundwater. It seems that spatial variation of hydrogeochemical facies of the study area is related to local lithology and groundwater storage.

\section{Discussions}

PHREEQC software was used to study the saturation indices (SI) of minerals dissolved in water, which indicates the potential for chemical equilibrium between water and minerals, and the likelihood of rock-water interactions [14]. The required data for SI calculation are the hydrochemical and mineralogical data, which are extracted from the result of XRD [5,7]. Specifically, the groundwater evolution occur only in the Fluviomarine Plain $\left(\mathrm{F}_{\mathrm{m}}\right)$, namely the groundwater facies from fresh water $\left(\mathrm{Ca}-\mathrm{HCO}_{3}\right)$ into mixed water $\left(\mathrm{Na}-\mathrm{Ca}-\mathrm{HCO}_{3}\right)$ and saline water $(\mathrm{Na}-\mathrm{Cl})$, as shown in Fig.5 and 6. The SI values for anorthite, augite, gypsum and halite in different groundwater facies are presented in Fig.7.

\subsection{Mineral saturation index (SI) in fresh water on the Fluviomarine Plain Unit}

The water which is trapped in the Fluviomarine Plain $\left(\mathrm{F}_{\mathrm{m}}\right)$ is fresh $\left(\mathrm{Ca}-\mathrm{HCO}_{3}\right)$ type with low TDS $(<500 \mathrm{mg} / \mathrm{L})$. Samples grouping in fresh water come from an environment where anorthite and augite would probably have in the study area. The SI value of anorthite for fresh water in upgradient (recharge) area ranges from -0.7 to +0.5 . Most of samples are nearly equilibrium and a few are slightly over-saturated (Fig.7a). This may be due to dissolution of augite (-5.9 $\leq \mathrm{SI}$ augite $\geq-5.4)$ (Fig.7b) and gypsum ($3.0 \leq \mathrm{SI}_{\text {gypsum }} \geq-2.1$ ) (Fig.7c) by water has already saturated with respect to calcium-bearing mineral (anorthite). These observations rule out for the contribution of dissolution process with respect to anorthite. This may improve over-saturation, which leads to precipitation of $\mathrm{Ca}^{2+}$ under suitable physico-chemical condition. Conversely,fresh water has negative SI value of halite from -8.4 to -6.2 (Fig.7d). There are obvious positive correlations between
TDS and SI for augite, halite and gypsum, indicating that these minerals are dissolving into water along flow path and will increase the contents of TDS.

\subsection{Mineral saturation index (SI) in mixed water on the Fluviomarine Plain Unit}

The mixed water spreads in lower hydraulic gradient area than that of fresh water and has the TDS ranging from 500 to $800 \mathrm{mg} / \mathrm{L}$, showing moderate concentration of dissolved solids in groundwater. The present of mixing $\mathrm{Ca}^{2+}$ and $\mathrm{Na}^{+}$ions points out that this water is associated with $\mathrm{Ca}-$ bearing minerals (anorthite, augite, gypsum) and $\mathrm{Na}$ bearing mineral (albite). These water samples display the SI value of anorthite, which ranges from -0.4 to +0.5 , indicating nearly equilibrium and slightly over-saturated with respect to these minerals (Fig.7a). There is no obvious correlation between TDS and SI for anorthite, indicating that this mineral does not keep dissolving along flow path. The slight increase in $\mathrm{Ca}^{2+}$ is further supported by the dissolution of augite (-5.3 $\leq \mathrm{SI}_{\text {augite }} \geq-5.4$ ) (Fig.7b) and gypsum $\left(-2.5 \leq \mathrm{SI}_{\text {gypsum }} \geq-1.9\right)$ (Fig.7c). Similarity, the SI value of halite is less than zero (-6.8 $\leq \mathrm{SI}_{\text {halite }} \geq-6.5$ ) (Fig.7d). Under-saturated minerals with respect to augite, gypsum and halite exhibit positive correlations with TDS, which suggest that these minerals could be feasibly dissolved along flow path of groundwater.

\subsection{Mineral saturation index (SI) in saline water on the Fluviomarine Plain Unit}

The saline water spreads in lowland area and it is characterized by high mineralization with TDS up to $800 \mathrm{mg} / \mathrm{L}$. The result of XRD shows that halite and gypsum are present in aquifer materials. However, halite and gypsum may not be abundant in the study area since these are highly under-saturated in groundwater. Saturation index of halite varies from -6.1 to -4.6 in all samples (Fig. 7d). Likewise, the saturation index of gypsum also ranges from -2.6 to -1.9 (Fig.7c).Water is generally apparent equilibrium with anorthite from -0.3 to +0.5 (Fig.7a) and undersaturation with augite from -5.3 to -5.4 (Fig.7b). This suggests that groundwater can enhance the dissolution of augite, gypsum and halite because of the slow circulation of groundwater in flat area, and lead to high values of TDS. In addition, the process of marine intrusion has also not appeared to occur, as evidenced by very low SI value of halite. Furthermore, to know how the process of groundwater evolution is from up-gradient to down-gradient, it is necessary to conduct the application of mass balance transport.

\subsection{Mineral saturation index (SI) in fresh water on the Sand Dunes Units}

The Sand Dunes Units are specifically characterized with low mineralization that form fresh water.The values of SI are under-saturation as the reacting of anorthite $(-2.5 \leq$ $\left.\mathrm{SI}_{\text {anorthite }} \geq-2.3\right)$, augite $\left(-3.8 \leq \mathrm{SI}_{\text {augite }} \geq-3.6\right)$ and gypsum 

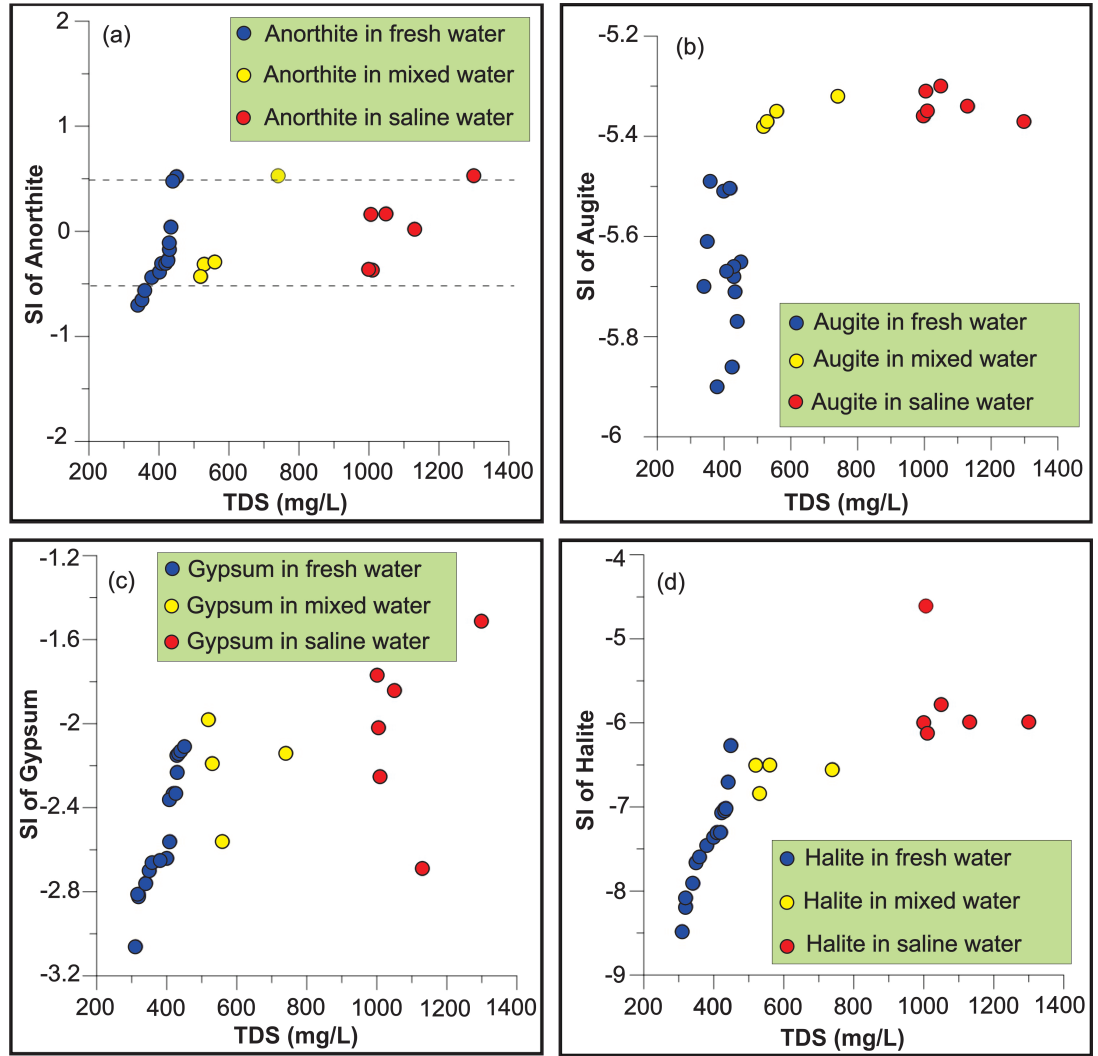

Fig. 7. Correlation between total dissolved solids (TDS) and saturation indices (SI) of (a) anorthite, (b) augite, (c) gypsum and (d) halite in different groundwater facies on the Fluviomarine Plain Unit

$\left(-3.7 \leq \mathrm{SI}_{\text {gypsum }} \geq-3.5\right)$, as in the groundwater flow of location $16(\mathrm{TDS}=310 \mathrm{mg} / \mathrm{L})$ to $11(\mathrm{TDS}=320 \mathrm{mg} / \mathrm{L})$. Although growing the TDS from up-gradient to downgradient, the groundwater facies do not cause the change in their chemical composition. Piper diagram (Fig.5) confirms this finding and it is further supported by very low SI values of halite $\left(-7.6 \leq \mathrm{SI}_{\text {halite }} \geq-6.7\right)$. Earlier, marine and eolian sands received less attention from groundwater point of view due to their high permeability and also difficulties in weathering.

\subsection{Mass balance transport}

Groundwater of the study area presents a wide range of hydrochemical facies (Fig.5). In the Fluviomarine Plain $\left(\mathrm{F}_{\mathrm{m}}\right)$, the sample numbers $24\left(\mathrm{Ca}-\mathrm{HCO}_{3}\right.$ water $), 20(\mathrm{Na}-$ $\mathrm{Ca}-\mathrm{HCO}_{3}$ water) and 19 (Na-Cl water) were taken along same flow path pointing down-gradient to calculate the moles of minerals and gases that must enter or leave into solution to account for the differences in hydrochemical compositions. The reason for selection of one flow path is to be data shortage. At first, the groundwater chemistry is dominated by fresh type $\left(\mathrm{Ca}-\mathrm{HCO}_{3}\right.$ water $)$ on higher Fluviomarine Plane $\left(\mathrm{F}_{\mathrm{m}}\right)$ designated by groundwater flow. Naturally, fresh water reveals the recharge area and undergoes the evolution with high $\mathrm{Na}^{+}$concentration during its journey. Natural acidification in groundwater is caused by $\mathrm{CO}_{2}$ production [15]. In recharge area, the infiltration water that is enriched in $\mathrm{CO}_{2}$ reacts with silicate minerals of alluvium sediments, particularly plagioclase feldspar. This will leach out ions like $\mathrm{Ca}^{2+}$ and $\mathrm{Na}^{+}$.
The presence of $\mathrm{HCO}_{3}{ }^{-}$is mainly due to the interaction of groundwater with atmospheric $\mathrm{CO}_{2}$. Despite the short resident time of groundwater, $\mathrm{CO}_{2}$ in sediments and presence of easily weathered aluminosilicate minerals (plagioclase) have contributed to observe fresh water in the Fluviomarine Plain $\left(\mathrm{F}_{\mathrm{m}}\right)$. Mineral alteration reactions controlling the groundwater evolution can be summarized as an illustration of hornblende and quartz according to continued dissolution of augite and plagioclase feldspars (Equation 3 ). The formation of hornblende and quartz may be associated with fine sand at the top of Wates Formation $\left(\mathrm{W}_{1}\right)$. $2.03 \mathrm{CO}_{2(\mathrm{~g})}+0.04$ Augite +0.67 Albite +1.74 Anorthite $\rightarrow$ 3.52 Hornblende + 1.79 Quartz

Locally, in lower Fluviomarine Plain $\left(\mathrm{F}_{\mathrm{m}}\right)$ compared with recharge area the mixed type $\left(\mathrm{Na}-\mathrm{Ca}-\mathrm{HCO}_{3}\right.$ water $)$ develop, with high $\mathrm{Na}^{+}$concentration associated with silts of fluvial (river) origin. Mixed type shows the recharge characteristics from calcium-rich materials and groundwater moves in unconfined aquifer. The $\left(\mathrm{Na}-\mathrm{Ca}-\mathrm{HCO}_{3}\right.$ water) type is very similar to fresh water, although dissolved solids increases moderately with distance from recharge area. This water is richer in the $\mathrm{HCO}_{3}{ }^{-}$ion than in previous case, although it has very similar $\mathrm{Ca}^{2+}$ contents. More intense water-rock reactions are indicated by higher rates of consumption of $\mathrm{CO}_{2}$ as for location 20 (Equation 4).

$$
\begin{aligned}
& 3.40 \mathrm{CO}_{2(\mathrm{~g})}+0.01 \mathrm{~K} \text {-feldspar }+0.09 \text { Augite }+1.30 \\
& \text { Anorthite }+2.50 \text { Albite } \rightarrow 4.00 \text { Hornblende }+ \\
& 0.13 \text { Kaolinite }+1.79 \text { Quartz }
\end{aligned}
$$


The Fluviomarine Plain $\left(\mathrm{F}_{\mathrm{m}}\right)$ in past geological time was shallow sea which then undergone the sedimentation so that it became the land. Sea water trapped in and experienced the intense evaporation and leaves salt crystals in aquifer [8]. There are some locations associated with sample 19 , that water is the $\mathrm{Na}-\mathrm{Cl}$ type, which is characterized by high dissolved solids spread due to the dissolution of salt crystals (halite) in flat area of the Fluviomarine Plain $\left(\mathrm{F}_{\mathrm{m}}\right)$. Dissolution of plagioclase feldspars proceeds to the formation of secondary clay minerals [15]. While groundwater traps in marine clay deposits for a long time,ion exchange takes place on the surface of clay minerals. The $\mathrm{Na}^{+}$and $\mathrm{Cl}^{-}$ions leached out from clays and $\mathrm{Ca}^{2+}$ adsorbed from clay minerals have modified the water chemistry, which was already saturated $\mathrm{Ca}^{2+}$ ions in fresh water of up-gradient (recharge) area (Equation 5).

$$
4.58 \mathrm{CO}_{2(\mathrm{~g})}+0.05 \text { Augite }+0.29 \text { Halite }+1.17 \text { Anorthite }
$$$$
+2.11 \text { Albite } \rightarrow 3.81 \text { Montmorillonite }+0.40 \text { Kaolinite }
$$

In comparison with the Fluviomarine Plain $\left(\mathrm{F}_{\mathrm{m}}\right)$, the increasing amounts of $\mathrm{Fe}_{2} \mathrm{O}_{3}$ and $\mathrm{MgO}$ have associated to the accumulation of iron oxides (hematite) and augite as poorly soluble mineral phase in the Sand Dunes Units, which are covered by eolian and marine sands containing fresh water, forming a layer of aquifer. The vertical flow system corresponds to locations of 16 and 11 which have the $\left(\mathrm{Ca}-\mathrm{HCO}_{3}\right.$ water) water on the units of Sand Dunes. Groundwater flow is local, so that its travel time from inflow to outflow is short. Furthermore, the weathering potential is compensated by overall increase in the amount of hematite and augite. Consequently, mineral alteration reactions do not change too much because of its fresh condition. That is why groundwater facies do not change in the Sand Dunes.

\section{Conclusions}

The study area is composed of typical alluvial deposits where silicate minerals are slightly weathered, moderately weathered and highly weathered. Fine sands indicates slightly weathered degree, while silts shows moderate weathering. The latter represents highly weathered degree leading to the formation of clays. Water samples from fine sands are mainly dominated by $\mathrm{Ca}-\mathrm{HCO}_{3}$ type, and from silts also have $\mathrm{Na}-\mathrm{Ca}-\mathrm{HCO}_{3}$ water, but groundwater in clay formation is mainly of the $\mathrm{Na}-\mathrm{Cl}$ type. Groundwater facies have been attributed to a number of factors, including mineral dissolution and adsorption are most important ones, but mixing process cannot be ignored. Silicate dissolution was reflected in low ions dominated by calcium and bicarbonate in fresh water. Water salinity with highest dissolved solids was caused by halite dissolution and calcium adsorption on clays. Mixed type was indicated by moderate ions. Overall, groundwater chemistry in the study area is controlled by prevailing lithology apart from marine intrusion. In conclusion, the greater importance is given for indiscriminate abstraction of water in the study area and opens new perspectives for groundwater potential occurring during pumping.

The authors would like to thank AUN-Seed/Net Program for supporting research and Department of Geological Engineering, Gadjah Mada University for providing the required equipment.

\section{References}

[1] S. Venkatramanan, S.Y. Chung, T. Ramkumar, G. Gnanachandrasamy, S. Vasudevan, S.Y. Lee, J. , Environ. Earth Sci 73, 13 (2015)

[2] A.J. Adewumi, A.Y.B. Anifowose, F.O. Olabode, T.A. Laniyan, J. Uniwersytet Slaski 7, 31 (2018)

[3] A. Jafar Ahamed, S. Ananthakrishnan, K. Loganathan, K. Manikandan, J. Appl. Water Sci 3, 8 (2013)

[4] Md. Mostafizur Rahman, M. Atikul Islam, Anwar Zahid, Md. Shazadur Rahman, M.J. Islam, Yeasmin Akter, Mashura Shammi, Md. Bodrud-Doza, Balaram Roy, J. WATER QUAL EXPOS HEA 9, 15 (2016)

[5] P. P. Thin, Assessment of groundwater chemistry in Wates Coastal Aquifer, Kulon Progo, Yogyakarta Special Province, Indonesia (Dissertation, Universitas Gadjah Mada, 2019)

[6] P.P. Thin, H. Hendrayana, W. Wilopo, S. Kawasaki, J. Degraded and Mining Lands Management 5, 12 (2018)

[7] P.P. Thin, H. Hendrayana, W. Wilopo, S. Kawasaki, Source of groundwater salinity in Wates Sub-district, Kulon Progo, Yogyakarta Special Province, Indonesia (Proceedings of the 12th SEATUC Symposium, Universitas Gadjah Mada, 2018)

[8] L.W. Santosa, Hidrostratigrafi akuifer sebagai geoindikator genesis bentuk lahan di wilayah Kepesisiran kabupaten Kulonprogo, daerah istimew Yogyakarta (Proceedings of the Forum Geografi, Universitas Gadjah Mada, 2012)

[9] A.M. Piper, J. AGU 25, 10 (1944)

[10] S.Ndoye, C. Fontaine, C.B. Gaye, M. Razack, J. Water 10, 20 (2018)

[11] H.W. Nesbitt, G.M. Young, J. Geol 97, 17 (1990)

[12] M.A. Summerfield, Global geomorphology (John Wiley and Sons, New York, 1991)

[13] MacDonald and Partners, Greater Yogyakarta groundwater resources study: groundwater 3 (Government of the Republic of Indonesia, 1984)

[14] D.L. Parkhurst, C.A.J. Appelo, User's guide to PHREEQC (version 3)- a computer program for speciation, batch-reaction, one dimensional transport, and inverse geochemical calculations (U.S Geological Survey, Denver, Colorado, 2013)

[15] J. Guo, F. Wang, R.D. Vogt, Y. Zhang, C. Liu, J. Sci. Rep 5, 8 (2015) 